Tradition and Prudence in Locke's Exceptions to Toleration

Author(s): David J. Lorenzo

Source: American Journal of Political Science, Vol. 47, No. 2 (Apr., 2003), pp. 248-258

Published by: Midwest Political Science Association

Stable URL: http://www.jstor.org/stable/3186136

Accessed: 20/07/2009 12:25

Your use of the JSTOR archive indicates your acceptance of JSTOR's Terms and Conditions of Use, available at http://www.jstor.org/page/info/about/policies/terms.jsp. JSTOR's Terms and Conditions of Use provides, in part, that unless you have obtained prior permission, you may not download an entire issue of a journal or multiple copies of articles, and you may use content in the JSTOR archive only for your personal, non-commercial use.

Please contact the publisher regarding any further use of this work. Publisher contact information may be obtained at http://www.jstor.org/action/showPublisher?publisherCode=mpsa.

Each copy of any part of a JSTOR transmission must contain the same copyright notice that appears on the screen or printed page of such transmission.

JSTOR is a not-for-profit organization founded in 1995 to build trusted digital archives for scholarship. We work with the scholarly community to preserve their work and the materials they rely upon, and to build a common research platform that promotes the discovery and use of these resources. For more information about JSTOR, please contact support@jstor.org. 


\title{
Tradition and Prudence in Locke's Exceptions to Toleration
}

\author{
David J. Lorenzo Jamestown College
}

Why did Locke exclude Catholics and atheists from toleration? Not, I contend, because he was trapped by his context, but because his prudential approach and practical judgments led him to traditional texts. I make this argument first by outlining the connections among prudential exceptionality, practical judgments, and traditional texts. I then describe important continuities between conventional English understandings of the relationship between state and religion and Locke's writings on toleration, discuss Locke's conception of rights, and illustrate his use of prudential exceptions and distinctions. I conclude by arguing that Locke's problems are relevant to assessing contemporary liberal discussions of toleration and the separation of state and religion that lean heavily on practical justifications.

$\mathrm{W}$ hy did Locke exclude Catholics and atheists from toleration when he otherwise supported an extensive set of religious freedoms? While the context of seventeenth-century England is important, I point to the mechanics of his discussion of toleration as the critical factor in the exceptions to toleration he made, particularly in the way prudence and practical reasoning connect his conclusions with traditional judgments. I argue further that Locke's problems are still relevant to our assessment of contemporary pragmatic justifications of toleration and the separation of state and religion, and that our understanding of those problems should persuade us to deploy textual justifications that are more extensive than the practical judgments those discussions invoke. ${ }^{1}$

Explanations for Locke's limited toleration. Explanations for Locke's failure to embrace a universal toleration vary. Some analysts, such as Cranston (1991, 81), Schochet $(1992,52)$, and Murphy $(2001,225)$, assign a deterministic role to his experiences and contexts. In their view events like the English Civil War, the "Popish Plot," the papal bulls aimed at the English government, and the Revocation of the Edict of Nantes decisively established the threat Catholics and atheists posed to toleration, order, and national security. Rawls (1999a, 92) more generally implies that had Locke lived in different circumstances he would have championed full toleration. Yet we know that Locke developed his position before the Edict of Nantes was revoked in 1685, before the "Popish Plot" was manufactured in 1681, and despite his residence in Cleve, a city he characterized as peaceful, stable, and tolerant of Catholics (Locke 1993a, 184). Moreover, contemporaries like Henry Stubbe and William Penn advocated a much broader toleration. Context alone therefore cannot explain his position.

Other analysts point to aspects of Locke's discussion of toleration. Some emphasize his general reliance on conventional views, such as Sandoz's (1972) argument that Locke's stance flowed from the English suspicion of enthusiasm and disbelief. Ashcraft (1986, 498; 1993, 203) points to the pervasive seventeenth-century English view of Catholics as loyal only to the pope, and argues that Locke used this conventional understanding to locate Catholics outside the "natural moral community." Marshall (1994, 365-6) and Harris (1998, 72, 123-4, 179-82) also argue that Locke's discussion of Catholics was influenced by convention as well as political contexts, while Dowretz $(1990,66,119-20)$ points to Locke's theism to account for his position on atheists.

Others emphasize Locke's pragmatic stance. Wootton (1993, 109-10) refers to Locke's judgment that while

David J. Lorenzo is Associate Professor of Political Science, Jamestown College, Box 6075 College Lane, Jamestown, ND 58401 (lorenzo@jc.edu).

My thanks to Dr. Stephen Reed, members of the Jamestown College Political Theory Seminar, and the AJPS reviewers for their comments on drafts of this article.

${ }^{1}$ For Locke's contemporary relevance, see Mendus (1989) and Waldron (1991).

American Journal of Political Science, Vol. 47, No. 2, April 2003, Pp. 248-258 
usually ideas are more important than actions, the ideas inherent in Catholicism and atheism "were pernicious" and therefore not to be tolerated. Kraynak (1980) argues that Locke opted for a limited toleration for prudence sake rather than from a principled commitment to freedom of conscience, a stance that did not call on the magistrate to tolerate views believed to threaten the state and order. And Mendus $(1989,26-7)$ maintains that Locke's rationalist attack on Augustinian justifications for intolerance, absent a positive defense of toleration, did not apply to justifications that referenced social order and state security.

These latter explanations illuminate several important points: Locke's reliance on prudential or pragmatic grounds, his concern with order, his failure to provide a positive defense of toleration, and the conventional views he endorsed. Yet they fail to explain fully the relationships among those elements, and subsequently fail to appreciate all the dangers that prudential thinking and practical judgments pose to toleration. In particular, while Mendus correctly holds that the combination of Locke's failure to provide a positive defense of toleration and his emphasis on prudence cleared the way for order-based justifications, she passes over the crucial role tradition plays in that mix. In contrast, the explanation I provide emphasizes the link between Locke's prudential method and the conventional views he endorsed. It runs like this.

Locke employed a natural-rights paradigm, maintaining that in the absence of a compelling reason for us not enjoying a right, we hold that right if it existed in the State of Nature and we did not give it up when we created government. We need not justify such political rights; rather it is up to the magistrate to justify any attempt to remove them. In this scheme rights are the rule and their refusal the exception. The advantages of this approach are considerable, but its weakness is that nothing but the naturalness of the right stands between the right as a rule and exceptions to the rule. Given that the Lockean conception of government makes the maintenance of order and security a primary duty for the magistrate, there are a considerable number of reasons linked with that duty that the magistrate can advance to justify removing a right. As Mendus argues, without a positive justification of rights, justifications for removing rights tied to order and security frees the magistrate selectively to exclude particular groups from enjoying rights even if he does not expand his power over all groups.

The link between prudence and tradition greatly increases the danger that the magistrate and analysts will follow this route. Garver (1987) argues that prudence is a mode of moral reasoning that falls between the conservative orderliness of algorithmic methods and the radical freedom of heuristics. To reason prudently means creating exceptions to general rules, clearing a space for practical judgment. When we apply this definition in the context of rights, we see that the judgmental freedom prudence provides creates an exception to the general award of rights, allowing the magistrate to use practical judgment at the citizen's expense. This procedure seems to fit nicely the process by which a political right is denied in a Lockean scheme, particularly given the importance of the magistrate's practical duties to protect order and security. But I suggest a further connection that runs through tradition. The conservative side of prudence which Garver argues produces stability of judgments often manifests itself in references to traditional texts from which derive both the nature of the exception to the rule and the practical judgment subsequently applied. Previously accepted categories of exceptionality and conventional lines of observation provide stability to a rule by ensuring that neither a particular case nor practical judgment destroys it. The contours of this tendency become clearer when we think about the nature of practical judgment and prudence. First, consider prudence in its generally accepted form as a cautious way of rendering decisions. Translated into the realm of rights, this understanding describes the initial prudential exception to the general rule granting rights as a rightly wary hesitation to confer those powers on some allegedly dangerous group of people. Traditionally identified dangers in turn are the most apparent. Second, if the practical judgment at the heart of prudence concerns itself with particulars and must lean on experience, as Aristotle (1962, Book VI, ch. 8, lines 10-20) holds, it naturally turns to traditional texts as taken for granted interpretations of experience. My contention therefore is that prudence will tend to utilize traditional texts initially to identify some set of groups as unfit to enjoy a right, and then follow through by using conventional appreciations of dangers to inform a practical judgment excepting permanently the groups deemed particularly treacherous. ${ }^{2}$ Prudence can make room for practical judgment without repudiating a general rule awarding rights, while simultaneously and ironically penalizing the traditionally marginalized.

I believe this explanation best accounts for Locke's stance on Catholics and atheists. I pursue this argument first by exploring the traditional components of Locke's understanding of toleration issues, and then by tracing the way his prudential arguments use that understanding to justify exceptions to toleration.

${ }^{2}$ Hirschmann's discussion of the "jeopardy thesis" also suggests that prudence begins with the attempt to protect the old and established and emphasizes the dangers marginal groups pose. See Hirschmann (1991, 86-120). 


\section{Locke and Tradition}

Much of the literature on Locke depicts him as a transitional figure who mixed tradition and innovation in his philosophical, political, and religious writings (Grant, 1987; Wolterstorff, 1996; Spellman, 1997, 3). This scholarship, along with the initial observation that Locke excluded Catholics and atheists from toleration, suggests significant qualifications are in order to Coffey's (2000, $55)$ and Schochet's $(1992,148)$ characterizations of the Letter Concerning Toleration as a radical document. Coffey maintains that Locke's rejection of the Augustinian justification of the political control of religion and his conception of the state are decisive and revolutionary. But this characterization describes Locke's relationship to only a portion of the relevant conventional views addressing the magistrate's power over religion. Despite some admittedly important divergences, there are important specific continuities between Locke and traditional English analysts regarding the groups who may or should be denied toleration and the reasons why the magistrate may regulate religious affairs. We find that English traditionalists, as with Locke, identified Catholics and atheists as unworthy of toleration because their views on posthumous punishment made them unreliable (Hull 1602; Elizabeth I 1602; Digges 1643; Charles, Earl of Derby 1669). And English pamphleteers referred to a range of arguments justifying governmental regulation of religion that include numerous references to the problems of order and security that Locke also emphasized.

Since Coffey stresses the radical character of the Letter and the difference between the early conservative Locke and the later radical Locke, ${ }^{3}$ I draw out these continuities by comparing the Locke of the Letter to traditional views and to the earlier Tracts on Government and Essay on Toleration with regard to these two subjects.

\section{Those Excluded from Toleration}

The early Locke was traditional in allowing the magistrate absolute discretion in matters of toleration and religion, arguing that no religious matter allows the individual to escape the magistrate's just authority. The laws of conscience, he argued in the Second Tract, are subordinate to the laws of the magistrate in the universal legal hierarchy. In a blanket allusion to dissenters, he dismissed all those who rejected the magistrate's religious laws, arguing that their objections were the products of their "weak minds" or anarchistic commitments to an inner

${ }^{3}$ Coffey (2000, 37); see also Dunn (1982, 28n), Harris (1998, passim), and Kelley (1991, 126-7). light (Locke 1993c, 174). In a letter dated in 1659, two years previous to the date assigned the First Tract, he explicitly mentioned the difficulties of tolerating Catholics, noting that their religious beliefs obligate them to obey a "master" other than the magistrate, one whose interests are "backed with an opinion of infallibility and holiness" (Locke 1993f, 138). In the Essay he backed away from his general condemnation of dissenters and instead concentrated on atheists and Catholics. He insisted that disbelief should not be tolerated, since belief in God is not a "speculative opinion" but rather the "foundation of all morality" and the factor that differentiates humans from "the most dangerous sort of wild beasts." He treated Catholics at greater length, identifying them with several positions disqualifying them from toleration: their loyalty to the pope, their failure to embrace toleration, and their civic unreliability (Locke 1993d, 188, 202-3). But at bottom he embraced a single traditional criterion connecting Catholics and atheists (as well as antinomian Protestants) in the Tracts and Essay: the refusal to link the consequences of one's actions to an objective posthumous judgment, a refusal generated by the atheist's unbelief and by the Catholic's belief in the pope's power to suspend or enforce God's judgment at will.

Locke identifies the same people as problematic in the Letter. ${ }^{4}$ While he generally grants Protestant dissenters toleration, he disqualified anyone who disavowed a belief in God and an afterlife, arguing that such a disavowal "dissolves" all moral ties between the individual and society. $\mathrm{He}$ also denied toleration to those who, by their membership in a particular church, "ipso facto deliver themselves up to the protection and service of a foreign prince," the fidelity to whom is guaranteed "on pain of eternal fire." This reference is complicated, for while his illustration of someone who should not to be tolerated by reason of his allegiance to a foreign prince was a "Mohammetan" (Locke 1993e, 426), ${ }^{5}$ he had previously used this language to refer to Catholics. He similarly disqualified those whose beliefs "are contrary to human society" or the moral rules that are necessary to civil society, as well as those who did not embrace toleration, those who taught that princes could be removed for their differences in religion, and those who taught that "faith is not to be kept with heretics." This is language he had previously used to identify the practical faults of Catholics that flow from their blind obedience to the Pope, though it may also encompass

${ }^{4}$ See Cranston $(1991,84)$, Harris $(1998,189)$, and Gough (1991, $60)$.

${ }^{5}$ While Matar (1999, 14-22) emphasizes the extent of the toleration Locke was prepared to extend Muslims, the Letter makes a connection between Muslims and an external political danger that is not made for Protestant nonconformists in general. 


\section{TABLE 1 Locke and Traditional Justifications of the Magistrate's Power Over Religion}

\begin{tabular}{|c|c|c|c|c|c|}
\hline \multirow{2}{*}{$\begin{array}{l}\text { Types of Arguments } \\
\text { Justifying Magisterial Power }\end{array}$} & \multicolumn{2}{|c|}{ Traditional Views } & \multicolumn{3}{|c|}{ Locke } \\
\hline & $1600-1670$ & $1670-1690$ & Tracts & Essay & Letter \\
\hline Protect Protestantism/Religion & $17(11 \%)$ & $15(24 \%)$ & \multirow{2}{*}{$\sqrt{ }$} & \multirow{7}{*}{$\begin{array}{l}\sqrt{ } \\
\sqrt{ }\end{array}$} & \multirow{7}{*}{$\begin{array}{l}\sqrt{ } \\
\sqrt{ }\end{array}$} \\
\hline Interests of Regime & $84(54 \%)$ & $21(33 \%)$ & & & \\
\hline Protect Laws & 0 & 5 & \multirow{5}{*}{$\begin{array}{l}\sqrt{ } \\
\sqrt{ }\end{array}$} & & \\
\hline Protect from Foreign Powers & 4 & 4 & & & \\
\hline Protect Order & 40 & 5 & & & \\
\hline Promote Loyalty & 21 & 3 & & & \\
\hline Protect Monarchy & 10 & 0 & & & \\
\hline Protect State & 9 & 4 & \multirow[t]{2}{*}{$\sqrt{ }$} & \multirow{2}{*}{$\sqrt{ }$} & \multirow[t]{2}{*}{$\sqrt{ }$} \\
\hline Interests of Populace & $26(17 \%)$ & $26(43 \%)$ & & & \\
\hline Freedom & 0 & 10 & \multirow[t]{5}{*}{$\sqrt{ }$} & & $\sqrt{ }$ \\
\hline Property & 4 & 2 & & & $\sqrt{ }$ \\
\hline Against Arbitrary Government & 6 & 11 & & & \\
\hline General Interests & 16 & 3 & & & \\
\hline Origins & $30(19 \%)$ & 0 & & & \\
\hline Power from God & 14 & 0 & \multirow[t]{2}{*}{$\sqrt{ }$} & & \\
\hline Power Natural to Government & 16 & 0 & & & \\
\hline Total Arguments & 157 & 62 & 6 & 3 & 5 \\
\hline
\end{tabular}

radical Protestant dissenters who follow the inspiration of an inner light (Locke, 1993e, 424-6; 1993d, 138). ${ }^{6}$

Despite the generality of its language, the Letter clearly identifies atheists and Catholics as groups undeserving of toleration, and does so on the same traditional grounds as the Tracts and Essay - their attitude toward posthumous judgment. As Schochet argues, toleration for Protestants alone seems to have satisfied Locke. ${ }^{7}$

\section{Arguments Justifying the Power of the Magistrate over Religious Affairs}

As demonstrated by the sample of arguments summarized in Table $1,{ }^{8}$ Locke's justifications of the magistrate's power over religious affairs in both his earlier and later work overlapped significantly with traditional justifications. In traditional justifications, the Tracts, the Essay, and the Letter, threats to social order and state security

\footnotetext{
${ }^{6}$ Also see Marshall $(1994,53,365)$.
}

${ }^{7}$ See Schochet $(1992,164)$. Cranston (1991) and Gough (1991, 74) differ from Schochet on whether the post-revolution toleration acts satisfied Locke.

${ }^{8}$ The pre-1670 arguments draw from 48 sources friendly to the Stuarts, while the 1670-1690 arguments draw from 26 sources that either anticipated, or justified, the Glorious Revolution. All sources are located in the Huntington Library. play a significant role. In turn Catholics and atheists as people who refuse to acknowledge an objective relationship between their actions and posthumous judgment are portrayed as threats to social order and state security, for in this shared view, backed by references to the Gunpowder Plot and the Civil War, that refusal allows people to escape the noncoercive bonds the magistrate generally uses to keep order and safeguard security and forces the magistrate to exercise his coercive powers over them.

Locke is at his most eclectic in the Tracts, providing several justifications for the magistrate's regulation of religion. In the First Tract he supplied the traditional Augustinian argument, asserting that we need "outward fences to secure the more substantial parts of religion." He also referred to order, arguing that we require regulation to restrain people from "destroy[ing] all that are not of their profession." Indulgence for those of "tender conscience" paved the way for the Civil War. Finally he referenced state security, arguing that religious claims often served as a "cloak" for rebellion and sedition (Locke 1993b, 1435). The Second Tract provided additional justifications. Locke explicitly permitted the magistrate to regulate religious affairs and promulgate laws regarding all matters "indifferent," including those pertaining to worship and ceremony. " $[\mathrm{H}]$ ow close," he observed, "the affinity and association is between all indifferent things, whether they 
concern religious ceremonies or secular customs" (Locke 1993c, 176). He again argued that religious freedom allows passion and zeal to create discord and sedition and referenced the need to secure "dignity, decency and order." He made a variation of the Augustinian argument, holding that the magistrate may regulate religion to preserve "wellloved national customs" that allow people more easily to embrace the faith. But more generally he argued that God has given the magistrate power over all religious affairs because that power is essential to the authority needed to preserve humankind (Locke 1993c, 153, 155-7).

Locke reverted to a reduced set of justifications in the Essay by concentrating on order and security. He argued variously that the magistrate may regulate religious opinions when they "tend to the disturbance of the state," "tend to destabilize the government," or even "cause greater inconvenience than advantages to the community." He also asserted the duty of the magistrate to move against people who hold opinions "destructive of human society." Significantly he summed up by asserting that prudence should guide the magistrate on all matters "indifferent" (Locke 1993d, 191-3, 197, 201).

The Letter, like the Essay, concentrated mostly on justifications related to order and the security of the state, while adding intolerance (itself a category Protestants traditionally used to disqualify Catholics) and threats to formerly monastic property. In general it held the magistrate need not tolerate actions in the religious realm that are unlawful in the secular. Since Locke's example was infanticide, the implication is that such actions are related to order in general. More particularly he repeated his assertion from the Essay that the magistrate has a duty to forbid "opinions contrary to human society." For reasons of national security he also gave the magistrate authority over people who follow foreign religious leaders. Finally he invoked the need to safeguard social and political order in general by giving the magistrate the power to rid the state of people who, lacking a belief in God, cannot be trusted to hold to promises, oaths, and covenants (Locke 1993e, 414-6). Thus while Locke rejected his earlier contention that the magistrate's duty to preserve humankind gives him full power over all affairs, he continued selectively to use that duty to justify significant amounts of religious regulation by alluding to the perceived threats particular religious views pose to the state and society.

Referring to the chart above, we also see that despite his abandonment of Augustinian justifications, Locke's position on this subject remained traditional in important respects, as his remaining justifications overlapped with several important traditional arguments. The Letter invoked five of the 13 traditional justifications found in the sample, accounting for $37 \%$ of the total traditional ar- guments. Indeed, several points suggest that Locke was in closer company with the supporters of the Stuart regime in his justification of state regulation of religious matters for purposes of order and security than to many supporters of the religious establishment set up by the Glorious Revolution. ${ }^{9}$ Like Locke, 39 of 48 supporters of regulation who published before 1670 cited problems of order, while 26 cited security. Considerably fewer writers referred to these arguments in the post-1670s sample (five of 26 for order, six of 26 for security).

Locke's linkages of Catholics to disloyalty and atheists to disorder were also traditional. Thirteen of the 21 arguments in the pre-1670s sample that referenced loyalty tied the problem to Catholics, as did six of the nine that cited threats to the state, and the five that referenced threats from foreign governments. Likewise in arguments leading up to and immediately following the Glorious Revolution, three of four writers who cited threats from foreign powers, the three who cited problems of loyalty, and the four who cited the need to protect the state linked these problems with Catholicism. Typical of all these arguments is John Gordon's early warning to James I that
"So as you that no sooner subject your selfe unto their [the Popes'] lawes, but upon the first dislike, they will absolve and free your subjects from their oath of obedience due unto their true and lawfull King, they will depose you at their pleasures, and give your crownes to whom they like. .." (Gordon $1603,46-7)$

Locke's linkage of disorder with atheists was equally traditional, reflecting more closely the arguments supporters of the Stuart establishment utilized than those the backers of the Revolution deployed. None of the five authors in the sample taken from the period between 1670 and 1690 who cited order referred to the problem of atheism. They instead referred to problems of Protestant dissenters. However, 14 of the 39 from the earlier sample did. Locke's argument was eerily similar to those of one Daniel Scargill in 1669 , who disavowed his adherence to atheism on the grounds that

"all persons so principled [as Hobbists and atheists] ought to be held by all mankinde as the most dangerous and declared enemies of the common faith amongst men. That they are not to be trusted upon any obligation of their faith, or pretensions

\footnotetext{
${ }^{9}$ Murphy (2001, 11-2, 151-2, 211, 217) argues that conventional anti-tolerationist arguments invoked security and order, but does not link this observation to Locke's use of those arguments.
} 
to piety, loyalty, or common honesty. ... but, that by those principles, destructive to all society and commerce amongst men, they may and do delude and defeat all Oaths and Protestations, all faith given to God or man." (Scargill 1669, 5-6)

Thus Locke retained customary, marginalizing descriptions and evaluations of Catholics and atheists, and adopted the traditional solution-governmental control-to the "problems" they posed precisely because he adopted parts of the traditional texts that painted those people as dangerous. Note also that the traditional problems he identified with the presence of Catholics and atheists are mostly connected with the magistrate's duty to preserve mankind, a duty that Locke asserts is central to the state's function (Kelly 1991, 131-3).

\section{Principles and Prudence}

If Locke retained important traditional views regarding the magistrate's role in religious affairs, how did those views find their way into his discussion of religious freedom? As I outlined above, I believe it was through prudential limitations on toleration rights that were unopposed by any positive defense. For Locke, prudence qualifies, or makes exceptions to, the imputation of rights by highlighting the importance of particular, traditional distinctions. ${ }^{10}$

To understand how his views on this subject were informed by distinctions and exceptions, we turn first to the limitations on moral generalizations he recognized.

\section{Limitations on Locke's Generalizations}

Locke repeatedly referred to morality as a subject we can "know" with certainty (Locke 1959, Book III, Ch. XI; Book IV, Chs. III and XII). By understanding morality in mixed modes (that is, by understanding the abstract relationships among ideas, both simple and complex), Locke argued we derive universally applicable rules that transcend contextual limitations in our exercise of morality. However, he also highlighted the difficulties and obstacles we face in formulating and following moral generalizations. First he pointed to our inability to represent moral ideas outside our minds in ways that are precisely true to their mental contours and that are capable of exact replication over time. Second, he discussed the complexity of moral ideas, in that they are found in bundles.

\footnotetext{
${ }^{10}$ For different views of the interplay between generalizations and distinctions in Locke's discussion, see Ashcraft $(1993,207)$ and Coffey $(2000,56-7,186)$.
}

This characteristic brings "inconveniences" in the form of our inability mentally to replicate moral ideas exactly over time, and in the difficulties of holding in our mind all relationships such that we may with confidence make significant comparisons among ideas. Finally he argued that we have a weakness for power, wealth, public applause, and self-esteem that keeps many of us in a kind of "Egyptian bondage."11

In addition to problems with attaining a complete understanding of moral principles, Grant (1987, 202-3) points to the necessary and limiting role experience played in Locke's moral framework. She notes that Locke was careful to argue that experience must inform the application of a "true" outcome of a mixed mode of reasoning. In her view, Locke believed that rationality as a faculty exercised to its fullest must apprehend not only logical relationships, but also the character of the world, individuals' relationships with one another, and their relationship with God, otherwise God created humans imperfectly by endowing them with a superfluous capacity of observation. We know by experience that the application of a rule is correct by the pain or pleasure it brings, just as we know that a rule is correct in the abstract by our discernment of logical relationships among ideas. Locke, Grant argues, saw the universe as seamlessly rational, not only because knowledge of simple modes reinforces that of mixed modes, but also because moral rules in practical settings requires both types of knowledge.

If this is the case, then it appears that operational principles must include the uncertainty that Locke argued characterizes the experiential mode of knowing, an uncertainty that qualifies those principles (Grant 1987, 204). In the Essay on Human Understanding (Book IV, Ch. XX) Locke emphasized the problems of creating operational principles and outlined a variety of ways in which we may be mistaken in our understanding of them. His discussion of "Wrong Assent, or Error" described the epistemological problems one encounters when following principles, including doubts concerning their validity, the role of tradition and authority, and contamination by "passions and inclinations." As in his earlier discussion of the problems of adhering to man's laws and public opinion (Book II, Ch. XXVIII), he argued that all principles should be subject to continuous experiential analysis.

Locke therefore seems to have held that even when we discover a general principle of scientific morality and

${ }^{11}$ Locke (1959, Book IV, Ch. III, 209-12). On the Reasonableness of Christianity (Section 243, 176-81 is similarly ambivalent regarding our ability rationally to apprehend a scientific morality. For contrasting views on Locke's belief in the attainability of a science of ethics, see Fraser's discussion in Locke (1959), and Grant (1987, 23-6). 
unite it with experience, the resulting synthetic generalization must be continually subjected to the test of experience. To operate in the world in a way that allows humans to fulfill their duty to justify rationally their every judgment, "operational principles" sometimes lose the character of generalizations. Our acceptance and application of a principle must be justified by (or is open to criticism by) experiential judgments. The only rationally defensible generalizations under this procedure are those limited by the stuff that informs experiential judgments: contexts. Principles may apply differently in different contexts or be inapplicable in some cases. Contexts can create distinctions limiting the reach of principles and generalizations, thereby creating exceptions to them. While the limitations he recognized in the Essay on Human Understanding have to do with our ability rationally to apprehend the correct set of principles, Locke's discussion of toleration identified another important limitation, one that is connected with experience: prudence.

\section{Prudence and Rights}

As the product of a generalization limiting the power of the magistrate, toleration is a political right for Locke. ${ }^{12}$ We must therefore understand Locke's conception of rights to understand the connection between prudence and toleration in his scheme.

In The Second Treatise (e.g., Ch. II., paragraph 8), rights are defined as things that someone may lawfully do, in reference either to Natural Law or to human law. These powers in turn are limited by the general rule that we should preserve others and ourselves. Under Natural Law in the State of Nature we all enjoy a complete freedom from subjection and exercise all rights. Under human law, duly-authorized magistrates exercise the rights we give up to government, while the rights of ordinary citizens are set by the limits on the powers of the magistrate that flow from the terms of our consent, Natural Law, and the tasks of government. These rights of citizens are political rights, and may be defined as the circumstances of our natural existence (freedom and equality under Natural Law) that remain after government correctly applies Natural Law and properly exercises its rights. ${ }^{13}$ They exist not because it is necessary that we be free in order to fulfill some aspect of our being, or in order that we might exercise some crucial component of our inherent capacities, but because

\footnotetext{
${ }^{12}$ Here I disagree with Mendus (1989, 39), Kelly (1991, 144), and Ashcraft $(1923,205-6)$ and agree with Waldron $(1991,112)$ and Schochet $(1992,151)$.

${ }^{13}$ Locke (1993g, Ch. IX, paragraphs 130-1), and Gough (1991, 678).
}

government cannot rationally justify a policy forbidding us from acting on our remaining natural liberty.

Lockean political rights therefore have two important characteristics. One, they are negatively rather than positively justified in that their substance is derived from powers left over after we grant government its necessary powers. Second political rights, like all rights, are circumscribed by the duty to preserve mankind that all, including governments, hold. Put together these characteristics act as important qualifications. All political rights in practice are limited by government's ability to justify their contraction or refusal by reference to contextual and experiential interpretations of its duty. Insofar then as the principles and generalizations that elucidate political rights can limit government's power by referencing consent and limited government, contexts and interpretations of experience formulated into practical judgments likewise can qualify the application of those principles and generalizations, usually by referencing relevant distinctions. ${ }^{14}$

We see the first characteristic throughout Locke's discussion of toleration. Nowhere does he supply a generalized, positive justification of toleration on the part of the state. Instead, by criticizing a variety of traditional justifications for the magistrate's complete control of religious affairs in the Letter, he provided a negative justification of a limited toleration. ${ }^{15}$ While his delineation of the limits of government was effective in replying to people who justified the magistrate's power over all religious affairs based on God's grant of power to the magistrate, popular consent, or salvation, as a justificatory strategy, it did not and was not meant to exhaust the list of possible reasons why a magistrate could regulate religious affairs and deny toleration by referencing distinctive exceptions.

Locke even more explicitly embraced the second characteristic when in the Essay he invoked prudential grounds to allow the magistrate to grant a selective toleration. The reasoning the magistrate uses to fulfill his duty to extend toleration while maintaining order and security, Locke argued, is prudential as well as principled, and prudence is linked with particulars, not universals:

And thus far of toleration as it concerns the magistrate's duty. Having showed what he is in conscience bound to do, it will be not be amiss to consider a little what he ought to do in prudence.

But because the duties of men are contained in general established rules but their prudence is regulated by circumstances relating to themselves

\footnotetext{
${ }^{14}$ On this topic see Kelly $(1991,144)$ and Schochet $(1992,162)$.

${ }^{15}$ Locke (1993e, 394-6); Mendus (1989, 26-7); Waldron (1991, 112 8); Walker (1996, 205), and Marshall $(1994,66)$.
} 
in particular, it will be necessary in showing how much toleration is the magistrate's interest to come to particulars. (Locke 1993d, 201)

While Locke initiated this understanding of toleration in the Essay, he also employed it in the Letter. Exceptions and distinctions importantly inform the portions of both the Essay and Letter that developed Locke's understanding of the scope of toleration and the extent of the magistrate's powers. In both places he carefully distinguished among beliefs and spheres of activity based upon an experiential understanding of their relationship to governmental functions. In the Essay he marked the difference between actions and interests that do not affect the state or others and those that do; the difference between things destructive of the foundation of society and those that are not; and the difference between things indifferent morally, but which are connected with political expediency, and those that are not so connected (Locke 1993d, 187, 201). Similarly in the Letter he distinguished between the internal and the external, and between things generally allowed by the magistrate and those generally not allowed. He also differentiated between dissenters who are Protestant and tolerant and those who are not.

These experientially informed distinctions led him in the Letter to argue that because religious beliefs are internal and generally do not affect the state or the rights of others, the magistrate is not justified in regulating them, thus justifying toleration by reference to natural rights and the principle of limited government. ${ }^{16}$ But he also held that the magistrate is justified in denying anyone the right to toleration when religious beliefs touch on order, security, property, and toleration itself. Contrary therefore to Ashcraft's analysis, Locke did allow the magistrate to subject toleration to the experiential test of political prudence. It was Locke's assertion that an analysis of the morals and politics of Catholics and atheists would show that those groups pose a danger to the order and security of a Protestant state that led him to permit the magistrate to carve exceptions out of the general boundary separating the public and private that otherwise nullified the magistrate's claim to power in the realm of religion. In turn, tradition informed the experiential distinctions he employed.

\section{Distinctions and Exceptions in Practice}

Locke created prudential exceptions to the rule of toleration when he differentiated between ordinary people and the potentially disorderly and disloyal. Included initially

${ }^{16}$ Locke (1993e, 394, 396); also Mendus (1989, 41) and Kelly (1991, 142). in the latter were not only Catholics and atheists, but also Protestant dissenters, who, as he had held in the Tracts, had been disorderly and threats to the security of the state during the Civil War (Locke 1993b, 153). If they were to be tolerated more distinctions had to be deployed in order to keep Catholics and atheists under the magistrate's thumb. Locke achieved this by emphasizing the traditional links between the latter groups and disorder and disloyalty as he applied practical reasoning to the question.

The first distinction relates to Wootton's observation that Locke failed to distinguish always between belief and action. As Wootton notes, Locke sometimes argued that action, not belief, should be the basis for government regulation. This was his main argument for assuming the loyalty and orderliness of ordinary Protestant Dissenters. Only their actions count; their theology matters little. At least theoretically this position applied to Catholics given his conclusion that a belief in transubstantiation was irrelevant to the magistrate. His emphasis here was on concrete actions, since actions alone impact the material interests governments have a duty to protect. Yet he abandoned this position when discussing atheists' beliefs regarding the afterlife, and Catholics' beliefs in the pope's authority over the Papal States, excommunication, and posthumous punishment. It need not be proved that atheists and Catholics acted on these beliefs in the ways Locke assumed. As tradition held, belief itself disqualified both groups from toleration. ${ }^{17}$

The second distinction involved his analysis of the alleged dangers particular groups posed to the state. Locke based his argument for tolerating Protestant dissenters on an observation and a generalization. The observation was that actions embedded in the religious services of Protestant dissenters (preaching, the consumption of bread and wine) were lawful in secular settings. The generalization was that we should assume the orderliness of ordinary Protestant dissenters as a group while treating separately the actions of the unruly or seditious few. He concluded that Protestant dissenters should generally enjoy toleration, and if sedition did raise its head in dissenters' meetings the magistrate should only punish instances of that activity, not dissent itself. ${ }^{18}$ Thus Locke separated the particular seditious few from the bulk of the dissenting Protestant population as a way of incorporating the latter under the wing of toleration without denying the magistrate the right to protect law and order. In this argument he presented a progressive response to those who pointed to

\footnotetext{
${ }^{17}$ Locke seems to have carried over his position on Catholics from the Essay on Toleration (1993d, 197).

${ }^{18}$ Locke $(1993 \mathrm{e}, 430)$. As indicated earlier, this toleration did not seem to extend to antinomian Protestant dissenters.
} 
the "fact" that Protestant dissenters had acted seditiously in the past and fomented the disorders that culminated in the Civil War. Instead of legislating by religious category he extended toleration to all ordinary Protestant dissenters and justified punishing only those who actually were disorderly.

We look in vain for this argument when it comes to Catholics and atheists. Locke put aside his observation that religious exercises and beliefs in themselves have no political ramifications and argued that no Catholic would be loyal and no atheist trustworthy in his oaths and promises. We find no generalized toleration here; instead, when we look beyond the code words, the traditional religious categories of "Catholic" and "atheist" became the basis upon which Locke's magistrate might use his coercive power rather than the actions of those who disturb the peace or endanger the state.

The final distinction involved Locke's invocation of human nature and factual observations. In contrast with his earlier position in the Tracts, he argued that while Protestant dissenters did have a history of disorderliness, their disorder stemmed from their experiences rather than from their dissent. To use the terminology of the Essay on Human Understanding, Locke gave his "assent" to the proposition that Protestant dissenters would remain orderly if tolerated, based on the probable truth of an observation. The observation was that disturbances were natural reactions to the fact that dissenters were "stripped of the goods which they have got by their honest industry" and "delivered up for a prey to other men's violence and rapine" (Locke 1993e, 432). As Farr (1987, 51-72) would put it, Locke used historical evidence and anthropological views to reject the traditional hypothesis (Protestant dissenters are always disorderly) in favor of a new one (Protestant dissenters are disorderly only when they are not tolerated) because the new hypothesis shed more light on the social situation than did the earlier. Yet Locke departed from this intellectual course when he withheld his assent to the proposition that Catholics and atheists would remain loyal and orderly if tolerated. While Locke explained away the past misdemeanors of Protestant dissenters he failed to excuse Catholics and atheists despite decades of punitive English laws. He instead privileged the traditional conclusions drawn from the Gunpowder Plot and the Civil War. ${ }^{19}$

For Locke, then, the dangers atheists and Catholics posed to communities were facts of our existence that justified prudentially limiting the imputation of privacy

${ }^{19}$ Locke (1993e, 409; 1959, Book II, Ch. XXVIII). Also see Spellman $(1997,46)$ and Wootton $(1993,109)$. For a contrary view see Murphy $(2001,211-7)$. and harmlessness to religious beliefs that made toleration rationally possible. While he was aware that tradition distorts our reason, he thought that employing practical judgments would allow him to sidestep that problem, as he did when he considered the case of Protestant dissenters. But the construction of the experience he used to make those judgments was deeply indebted to tradition, causing his justification of toleration to exclude Catholics and atheists by reason of their traditional marginalization.

\section{Conclusion}

I argue that the problems with Locke's position identified here are particularly relevant to some contemporary approaches to the problems of toleration and the separation of state and religion. Those approaches emphasize experience and practical judgments in justifications while disregarding their connection with tradition.

For example, Murphy depicts liberal toleration as a minimal concept that we should justify by recourse to pragmatic arguments. In doing so he draws upon a history of toleration debates to illustrate the usefulness and limitations of a Hobbesian politics of toleration. Toleration, he argues, came about as a result of practical reasoning, "painful compromises" and "hard-headed judgments," rather than a "progressive flourishing of a preordained progress." His position is summed up by his approving reference to Larmore's and Shklar's limited, political, and pragmatic conception of liberalism. In his view we best understand and justify toleration by reference to practical judgments linked to the protection of conscience rather than by expanding the concept to justify something more than the modus vivendi state. ${ }^{20}$

Rawls (1993a, 1993b) meanwhile depicts toleration as the core of a contemporary liberal consensus on the desirability of multiple conceptions of the good, a consensus that does not depend upon controversial references to basic moral positions. Despite their differences on the nature of toleration and the desirable state, this understanding leads Rawls to rely upon many of the same arguments as Murphy when he discusses religious freedom. In particular Rawls wishes to model justification of separation and toleration upon the experiential, historical elements of Madison's "Memorial and Remonstrance," arguing that such arguments alone can appeal to and are available to everyone.

\footnotetext{
${ }^{20}$ Murphy (2001, 283-8, especially 287); see also Yack (1996). While Murphy emphasizes the variety of arguments historically used to justify toleration, he does so to defend a sphere of public reasoning that would include religious arguments, not to establish the importance of texts to political justifications of toleration and separation.
} 
But as we have seen here, to privilege experience, history, and practical reasoning in this manner is problematic, particularly in the absence of other, positive justifications. One could argue that using primarily pragmatic arguments to justify toleration runs the same risk as justifying toleration solely on natural rights grounds. Without thicker justifications it is easy to construct a practical case for denying toleration. Moreover, the historical, experiential, practical, and pragmatic judgments that we would rely upon are often informed by traditional texts. If we wish to avoid drawing toleration in Murphy's terms as a "static" concept, I argue that we must recognize the important, hidden role traditional texts may play in practical, experiential judgments, as well as the need to create positive textual justifications of rights to counter those texts' tendency to drag backwards or freeze our understanding of toleration and separation.

The conclusions I draw flow from those observations. I argue that we must not consider the conceptualization and justification of toleration and separation in purely practical terms. Its blindness to the role texts play in interpreting experience has caused the pragmatic approach historically to favor the limitation of toleration and to rationalize the mixture of state and religion in almost equal measures to its justification of toleration and separation. In its place we must provide positive as well as practical justifications, particularly if we concede that prudential considerations may allow governments, under exceptional circumstances, to limit the freedom to act on religious beliefs. ${ }^{21}$ Affirmations of toleration and separation should first ground both free expression rights and separation principles in arguments holding that without the rights to be free of government interference to worship, and to be free of state imposed religious doctrines to choose our spiritual orientation, we are seriously diminished as persons. Mill's (1869) defense of religious liberty is one example of such an account, though I do not believe we should adopt his developmental scheme. Second, justifications should establish that those rights and principles are crucial to all persons and are relevant in all circumstances absent an immediate and particular threat to the rights of others. In creating such justifications we embrace the conclusion that purely practical justifications are not as useful as those mixed with positive arguments.

Finally I argue that we should not confine ourselves within a liberalism conceptualized as a "philosophy of politics, not a philosophy of man" when we create justifications. Rather we should appeal explicitly to texts in-

\footnotetext{
${ }^{21}$ For example, see Reynolds v. U.S., 1878; Prince v. Massachusetts, 1944; Braunfield v. Brown, 1961. Waldron (1991, 113-4) touches on this problem.
}

formed by a liberal anthropology, a liberal philosophy of history, and a liberal understanding of biography. These texts should root in an explicit description of human nature Locke's observations that spirituality is necessary to a fully human life but dangerous when mixed with state affairs. More, we should create historical and biographical texts highlighting a liberal understanding of the rewards of spirituality, the dangers of state involvement in spiritual matters, and the historical development of limited, secular governments. Only by employing such diverse, extended, and textual justifications of toleration and separation, I argue, will we address the dangers posed by traditional, practical, and marginalizing judgments. ${ }^{22}$

\section{References}

Aristotle, 1962. Nicomachean Ethics. Indianapolis: BobbsMerrill.

Ashcraft, R. 1993. "Religion and Lockean Natural Rights." In Religious Diversity and Human Rights, ed. I. Bloom, J. P. Martin, and W. L. Proudfoot. New York: Columbia University Press, 195-212.

Ashcraft, R. 1986. Revolutionary Politics and Locke's “Two Treatises on Government." Princeton: Princeton University Press.

Audi, R. 1989. "The Separation of Church and State and the Obligations of Citizenship." Philosophy and Public Affairs 18(3):259-96.

Audi, R. 2000. Religious Commitment and Secular Reason. New York: Cambridge University Press.

Charles, Earl of Derby. 1669. The Protestant Religion Is a Sure Foundation and Principle of a True Christian, and a Good Subject. London.

Coffey, J. 2000. Persecution and Toleration in Protestant England 1558-1669. New York: Longman.

Cranston, M. 1991. "John Locke and the Case for Toleration." In John Locke: A Letter on Toleration in Focus, ed. J. Horton and S. Mendus. New York: Routledge, 78-97.

Digges, Dudley. 1643. The Unlawfulness of Subjects Taking up Armes against their Soveraigne, in what case soever. London.

Dowretz, S. 1990. The Unvarnished Doctrine: Locke, Liberalism and the American Revolution. Durham: Duke University Press.

Dunn, J. 1982. The Political Thought of John Locke: An Historical Account of the Argument of the "Two Treatises of Government." New York: Cambridge University Press.

Dworkin, R. 1978. Taking Rights Seriously. Cambridge: Harvard University Press.

Elizabeth I, 1602. "A Proclamation for proceeding against Jesuites and Secular Priestes, their Receivers, Relieverers, and Maintainers." London.

${ }^{22}$ Contemporary liberals usually do not offer such extensive, textual justifications. See Dworkin (1978, 199, 272-8) and Audi (1989, 2000). Waldron (1991) and Mendus (1989) do provide materials for thicker justifications. Nederman (1994) provides a relatively thick, nonliberal justification. 
Farr, James. 1987. “The Way of Hypothesis: Locke on Method." Journal of the History of Ideas 48(1):51-72.

Garver, E. 1987. Machiavelli and the History of Prudence. Madison: University of Wisconsin Press.

Gordon, J. 1603. A Panegyrique of Congratulation for the Concord of the Realmes of Great Britaine in unitie of Religion, and Under one King. London.

Gough, J. W. 1991. "The Development of Locke's Belief in Toleration." In John Locke: A Letter on Toleration in Focus, ed. J. Horton and S. Mendus. New York: Routledge, 57-77.

Grant, R. 1987. John Locke's Liberalism. Chicago: University of Chicago Press.

Harris, I. 1998. The Mind of John Locke: A Study of Political Theory in its Political Setting. New York: Cambridge University Press.

Hirschmann, A. 1991. The Rhetoric of Reaction: Perversity, Futility, Jeopardy. Cambridge: Belknap Press of Harvard University Press.

Hull, John. 1602. The Unmasking of the Politike Atheist. London.

Kelly, P. J. 1991. "John Locke: Authority, Conscience, and Religious Toleration." In John Locke: A Letter on Toleration in Focus, ed. J. Horton and S. Mendus. New York: Routledge, 125-46.

Kraynak, R. 1980. "John Locke: From Absolutism to Toleration." American Political Science Review 74(1):53-69.

Locke, J. 1959. Essay on Human Understanding. New York: Dover.

Locke, J. 1965. On the Reasonableness of Christianity, ed., George W. Ewing. Chicago: Gateway.

Locke, J. 1993a. “Letter to Robert Boyle.” In The Political Writings of John Locke, ed. D. Wootton. New York: Penguin, 184-5.

Locke, J. 1993b. "First Tract on Government." In The Political Writings of John Locke, ed. D. Wootton. New York: Penguin, 141-5.

Locke, J. 1993c. "Second Tract on Government." In The Political Writings of John Locke, ed. D. Wootton. New York: Penguin, 152-77.

Locke, J. 1993d. “Essay on Toleration.” In The Political Writings of John Locke, ed. D. Wootton. New York: Penguin, 186-210.

Locke, J. 1993e. "Letter Concerning Toleration." In The Political Writings of John Locke, ed. D. Wootton. New York: Penguin, 390-436.

Locke, J. 1993f. "Letter to S.H." In The Political Writings of John Locke, ed. D. Wootton. New York: Penguin, 137-9.

Locke, J. 1993g. “Second Treatise on Government." In The Political Writings of John Locke, ed. D. Wootton. New York: Penguin, 261-387.

Marshall, J. 1994. John Locke: Resistance, Religion and Responsibility. New York: Cambridge University Press.
Matar, N. 1999. "The Toleration of Muslims in Renaissance England: Theory and Practice." In Religious Toleration: "The Variety of Rites" from Cyrus to Defoe, ed. J. C. Laursen. New York: St. Martin's Press, 127-46.

Mendus, S. 1989. Toleration and the Limits of Liberalism. Atlantic Highlands, NJ: Humanities Press International.

Mill, J. S. 1869. On Liberty. London: Longman's, Green, Reader and Dyer.

Murphy, A. 2001. Conscience and Community: Revisiting Toleration and Religious Dissent in Early Modern England and America. University Park: The Pennsylvania State University Press.

Nederman, C. 1994. “Tolerance and Community: A Medieval Communal Functionalist Argument for Religious Toleration." Journal of Politics 56(4):901-18.

Rawls, J. 1999a. "Constitutional Liberty and the Concept of Justice." In John Rawls: Collected Papers, ed. S. Freeman. Cambridge: Harvard University Press, 73-95.

Rawls, J. 1999b. “The Idea of Public Reason Revisited," In John Rawls: Collected Papers, ed. S. Freeman. Cambridge: Harvard University Press, 573-615.

Sandoz, E. 1972. "The Civil Theology of Liberal Democracy: Locke and His Predecessors." Journal of Politics, 34(1):2-36.

Scargill, D. 1669. The Recantation of Daniel Scargill, Publickly made before the University of Cambridge; in Great St. Maries, July 25, 1669. Cambridge.

Schochet, G. 1992. "John Locke and Religious Toleration." In The Revolution of 1688-1689: Changing Perspectives, ed. L. Schwoerer. New York: Cambridge University Press, 14764.

Spellman, W. 1997. John Locke. New York: St. Martin's Press.

Waldron, J. 1991. "Locke: Toleration and the Rationality of Persecution." In John Locke: A Letter on Toleration in Focus, ed. J. Horton and S. Mendus. New York: Routledge, 98124.

Walker, W. 1996. "Force, Metaphor and Persuasion in Locke's Letter on Toleration." In Difference and Dissent: Theories of Tolerance in Medieval and Early Modern Europe, ed. C. J. Nederman and J. C. Laursen. New York: Rowman and Littlefield, 205-29.

Wolterstorff, N. 1996. John Locke and the Ethics of Belief. New York: Cambridge University Press.

Wootton, D. 1993. The Political Writings of John Locke. New York: Mentor.

Yack, B. 1996. "Liberalism Without Illusions: An Introduction to Judith Shklar's Political Thought." In Liberalism Without Illusions: Essays on Liberal Theory and the Political Vision of Judith N. Shklar, ed. B. Yack. Chicago: University of Chicago Press, 1-13. 